\title{
PERANCANGAN SISTEM INFORMASI PERSEDIAAN BARANG PADA PT BINA SAN PRIMA KARAWANG
}

\author{
Dede Firmansyah Saefudin ${ }^{1}$, Yulikomalasari ${ }^{2}$, Dini Arianti ${ }^{3}$ \\ ${ }^{1}$ Teknik\&Informatika,Universitas Binasarana Informatika PSDKUKarawang, JalanBantenNo.1 \\ Karangpawitan Karawang Email:dede.dfs@bsi.ac.id \\ ${ }^{2}$ Teknik\&Informatika,Universitas Binasarana Informatika Jalan Kamal Raya No.18,ringroad \\ Barat,CengkarengJakartabarat,11710,Indonesia Email:yuli.yks@bsi.ac.id \\ ${ }^{3}$ Teknik\&Informatika,Universitas Binasarana Informatika PSDKU Karawang, JalanBantenNo.1 \\ Karangpawitan Karawang
}

\begin{abstract}
Abstrak
Persediaan barang dagang merupakan hal yang sangat penting bagi perusahaan dagang dan perusahaan manufaktur. Persediaan diperlukan untuk menciptakan penjualan guna menghasilkan laba. Persediaan merupakan aktiva lancar yang memiliki resiko cukup tinggi dalam kegiatan perusahaan jika tidak diperhatikan dengan benar. Proses persediaan barang yang ada di PT. Bina San Prima dapat dikatakan masih kurang efisien dan efektif karena semua masih dilakukan secara manual, mulai dari proses pencatatan data barang, proses data barang masuk dan data barang keluar, proses laporan data barang. Pengaksesan ini belum memiliki suatu sistem informasi persedian barang yang baik, juga untuk pemesanan data ke Supplier belum ada data minimum stok yang ditentukan agar pemesanan dapat dilakukan ke Supplier Sehingga mengakibatkan stok kadang-kadang sudah habis persediaannya baru dipesan ke Supplier, dan membuat terhambatnya barang apabila ada pembelian dari Customer. Aplikasi program merupakan alternatif pemecahan dari masalah yang dihadapi oleh perusahaan-perusahaan atau pun instansi, khususnya PT. Bina San Prima dalam hal ini khususnya pembuatan laporan persediaan barang. Dengan adanya aplikasi pemrograman ini pengisian dan penyimpanan data akan menjadi mudah dan lebih aman.
\end{abstract}

Kata Kunci: Perancangan Sistem Informasi Persediaan Barang

\section{Abstract}

Merchandise inventory is very important for trading companies and manufacturing companies. Inventory is needed to create sales for a profit. Inventories are current assets that have a high enough risk in company activities if they are not considered properly. The inventory process at PT. Bina San Prima can be said to be still inefficient and ineffective because everything is still done manually, starting from the process of recording goods data, processing incoming goods data and outgoing goods data, processing goods data reports. This access does not yet have a good inventory information system, also for ordering data from suppliers there is no minimum stock data specified so that orders can be made to the supplier so that sometimes the stock is out of stock and then ordered to the supplier, and it hampers the goods if there is a purchase from the customer. The program application is an alternative solution to the problems faced by 
companies or agencies, especially PT. Bina San Prima, in this case, especially in making inventory reports. With this programming application, filling and storing data will be easier and safer.

\section{Keywords: Inventory Information System Design}

\section{PENDAHULUAN}

Persediaan barang dagang merupakan hal yang sangat penting bagi perusahaan dagang dan perusahaan manufaktur. Persediaan diperlukan untuk menciptakan penjualan untuk menghasilkan laba. Persediaan merupakan aktiva lancar yang memilik resiko cukup tinggi dalam kegiatan perusahaan jika tidak diperhatikan dengan benar. Resiko yang mungkin ditimbulkan dapat berupa resiko fisik atau resiko keuangan. Misalnya dari segi fisik yaitu apabila terjadi kecurangan terhadap persediaan yang ada digudang karena kurangnya pengawasan dan terjadinya kerusakan barang yang mengakibatkan konsumen kecewa. Dan dari segi keuangan yaitu apabila terjadi kesalahan dalam pencatatan yang mengakibatkan kerugian perusahaan pada periode akuntansi.Dalam perusahaan industri istilah persediaan meliputi persediaan bahan baku, barang dalam proses, dan barang jadi.

Proses persedian barang yang ada di PT. Bina San Prima dapat dikatakan masih kurang efisien dan efektif karena semua masih dilakukan secara manual, mulai dari proses pencatatan data barang, proses data barang keluar, proses laporan data barang. Pengaksesan ini belum memiliki suatu sistem informasi persedian barang yang baik. Semua hal tersebut sering mengakibatkan hasil yang kurang teliti dan memakan waktu dan apabila terjadi kesalahan dalam pencatatan yang mengakibatkan kerugian perusahaan.

Berdasarkan permasalahan tersebut supaya semangkin efektif dan efisien pengolahan data dan informasi mengenai persedian barang yang ada serta menyusun persedian barang tiap periode secara sistematis pada PT. Bina San Prima. Maka dibutuhkan sebuah sistem informasi persedian barang yang sudah terkomputerisasi dengan baik sehingga kendala-kendala yang dapat teratasi.

\section{TINJAUAN PUSTAKA}

\subsection{Konsep Dasar Sistem}

\subsubsection{Pengertian Sistem}

1. Pengertian Sistem Secara Umum

Menurut Hayuningtyas (2018:6). Memberikan pengertian bahwa "Sistem dapat diartikan sebagai kesatuan dari bagian-bagian yang saling berkaitan untuk menghasilkan informasi dan tercapainya suatu tujuan".

2. Pengertian Sistem Informasi

Menurut (Yuli dan Dewi, 2015:13) menyimpulkan bahwa: Sistem informasi manajemen harus mampu memberikan informasi yang diperlukan oleh manajemen tersebut di berbagai tingkatan dan fungsi bisnis tersebut secara umum. Secara umum dapat diartikan bahwa informasi yang diterima oleh manajemen adalah informasi-informasi yang umum diperlukan oleh manajemen sesuai dengan posisinya.

3. Pengertian Sistem Persedian Barang

Menurut Poerwanta dalam Hayuningtyas (2018:6) memberikan pengertian bahwa "Bagian yang disediakan dalam proses yang terdapat dalam suatu perusahaan untuk diproduksi, 
Hal : $158-175$

serta barang jadi yang disediakan untuk memenuhi permintaan dari konsumen setiap waktu yang disimpan dan dirawat".

\subsubsection{Bahasa Pemrograman}

1. NetBeans

Menurut Nofriandi (2018:3). Memberikan pengertian bahwa "NetBeans merupakan sebuah aplikasi Integrated Development Enviroment (IDE) yang berbasis kan java dari sun Microsystems yang berjalan di atas swing dan banyak digunakan sekarang sebagai editor untuk berbagai bahas pemrograman.

2. Bahasa Pemrograman Java

Menurut Nofriandi (2018:3). Memberikan pengertian bahwa "Bahasa pemrograman java merupakan salah satu dari sekian banyak bahasa pemrograman yang dapat di jalankan di berbagai sistem operasi termasuk telpon genggam

\subsubsection{Basis Data (Database)}

1. MySQL (My Structure Query Languange)

Menurut Hikmah dkk, (2015:2). Memberikan pengertian bahwa "MySql (My Structure Query Language) adalah salah satu Database Management System (DBMS) dari sekian banyak DBMS, seperti Oracle, MS SQL, Postagre SQL, dan lainnya”.

2. PhpMyAdmin

Menurut Rahman, (2014:12). "PhpMyAdmin adalah aplikasi PHP sebagai administrator MySql. PhpMyadmin mendukung berbagai aktivitas MySql Seperti pengolahan data, table, relasi antara dan lain sebagainya".

\subsection{Teori Pendukung}

\subsubsection{Entity Relationship Diagram}

1. $\quad$ ERD (Entity Relationship Diagram)

Menurut Sulianta \& Umbara (2015:100). memberikan pengertian bahwa "ERD merupakan diagram yang digunakan untuk merancang table-tabel yang nantinya akan diimplementasikan pada basis data".

ERD ini di bentuk berdasarkan 3 element yaitu :

a. Entitas

Entitas adalah objek dalam bentuk fisik atau konsep. Entitas ini akan di buat unik atau berbeda dengan entitas lainnya, misalnya entitas mahasiswa, dosen, mata kuliah, dan sebagainya.

b. Atribut

Atribut adalah karakteristik atau property dari entitas, misalnya etitas mahasiswa memiliki atribut nomor induk mahasiswa (NIM), nama, alamat, jenis kelamin, hobi, dan lain-lain.

c. Relasi

Relasi adalah hubungan antar entitas yang satu dengan yang lainnya, misalnya terdapat hubungan antara entitas mahasiswa dengan mata kuliah karena mahasiswa nantinya akan mengambil mata kuliah.

\section{LRS (Logical Relationship Structure)}


Hal : $158-175$

Menurut Dhanta dalam Juniato dan Yusa Primaesha (2015:444) memberikan pengertian bahwa "LRS (Logical Record Structure) adalah representasi dari struktur record-record pada tabel-tabel yang terbentuk dari hasil antara himpunan entitas. Menentukan kardinalitas, jumlah table dan Foreign Key (FK)".

\subsubsection{Unifed Modelling Language (UML)}

Menurut Windu Gata dalam Hendini (2016:2) menyimpulkan bahwa: Unified Modeling Language (UML) adalah bahasa spesifikasi standar yang dipergunakan untuk mendokumentasikan, menspesifikasikan dan membanngun perangkat lunak. UML merupakan metodologi dalam mengembangkan sistem berorientasi objek dan juga merupakan alat untuk mendukung pengembangan sistem.

Alat bantu yang digunakan dalam perancangan berorientasi objek:

1. Use Case Diagram

Use case diagram merupakan pemodelan untuk kelakuakn (behavior) sistem informasi yang akan dibuat. Use case digunakan untuk mengetahui fungsi apa saja yang ada di dalam sistem informasi dan siapa saja yang berhak menggunakan fungsi-fungsi tersebut.

2. $\quad$ Diagram Aktivitas (Activity Diagram)

Activity Diagram menggambarkan workflow (aliran kerja) atau aktivitas dari sebuah sistem atau proses bisnis.

3. $\quad$ Diagram Urutan (Sequence Diagram)

Sequence Diagram menggambarkan kelakuan objek pada use case dengan mendeskripsikan waktu hidup objek dan pesan yang dikirimkan dan diterima antar objek.

4. $\quad$ Diagram Kelas (Class Diagram)

Merupakan hubungan antar kelas dan penjelasan detail tiap-tiap kelas di dalam model desain dari suatu sistem, juga memperlihatkan aturan-aturan dan tanggung jawab entitas yang menentukan perilaku sistem.

Class Diagram juga menunjukkan atribut-atribut dan operasi-operasi dari sebuah kelas dan constraint yang berhubungan dengan objek yang dikoneksikan. Class Diagram secara khas meliputi : Kelas (Class). Relasi Assosiations, Generalitation dan Aggregation, attribut (Attributes). operasi (operation/method) dan visibility, tingkat akses objek eksternal kepada suatu operasi atau attribut. Hubungan antar kelas mempunyai keterangan yang disebut dengan Multiplicity atau Cardinality.

5. Deployment Diagram

Deployment Diagram digunakan untuk menggambarkan detail bagaimana komponen disusun di infrastruktur sistem.

\section{Metode Penelitian}

\subsection{Model Pengembangan Perangkat Lunak}

Menurut Yurindra, (2017:43). mengemukakan bahwa "waterfall merupakan salah satu metode dalam SDLC yang mempunyai ciri khas pengerjaan yaitu setiap fase dalam waterfall harus diselesaikan terlebih dahulu sebelum melanjut ke fase selanjutnya".

Tahapan-tahapan dari metode waterfall adalah sebagai berikut:

1. Requirement Analysis 
Hal : $158-175$

Seluruh kebutuhan software harus bisa di dapatkan dalam faseini, termasuk didalamnya kegunaan software yang diharapkan pengguna dan batasan software.

2. System Design

Tahap ini dilakukan sebelum melakukan coding. Tahap ini bertujuan unutuk memberikan gambaran apa yang harus di kerjakan dan bagaimana tampilannya.

3. Implementation

Dalam tahap ini dilakukan pemrograman. Pembuatan software di pecah menjadi modul-modul yang nantinya akan digabungkan dalam tahap berikutnya.

4. Integration \& Testing

Ditahap ini dilakukan penggabungan modul-modul yang sudah dibuat dan dilakukan pengujian ini dilakukan untuk mengetahui apakah software yang dibuat telah sesuai dengan desainnya dan masih terdapat kesalahan atau tidak.

5. Operation \& Maintenance

Ini merupakan tahap terakhir dalam model waterfall. Software yang sudah dijalankan serta dilakukan pemeliharaan. Pemeliharan termasuk dalam memperbaiki kesalahan yang tidak dilakukan pada tahap sebelumnya.

\subsection{Teknik pengumpulan Data}

Teknik pengumpulan data yang digunakan oleh penulis dalam melakukan pengumpulan data adalah :

a. Observasi

Melakukan pengamatan secara langsung di lapangan, pada PT Bima San Prima khususnya di bagian persedian barang

b. Wawancara

Melakukan wawancara terhadap bagian persedian barang tentang tatacara persedian barang pada PT. Bima San Prima, mulai dari proses barang masuk proses barang keluar dan juga mengenai tentang sejarah perusahaan, visi-misi dan struktur organisasi perusahaan.

c. Studi Pustaka

Mencari studi kasus yang berkaitan dengan judul yang di ambil penulis tentang persedian barang.

\subsection{Ruang Lingkup}

Dalam perancangan penulisan persedian barang pada PT Bima San Prima ini diperlukan batasan masalah, agar permasalahan yang ditinjau tidak terlalu luas dan sesuai dengan maksud dan tujuan yang dicapai. Adapun batasan-batasan yang dibuat adalah sebagai berikut :

1. Admin

a. Proses input terhadap menu admin terdapat input data barang masuk, input data barang keluar, input data pelanggan dan input data supplier, input data barang.

b. Proses yang terjadi pada sistem bagian admin terdapat proses login, pengecekan stok barang, dan proses cetak.

c. Keluaran yang dihasilkan oleh aplikasi yaitu informasi laporan persedian barang, informasi laporan barang masuk, informasi laporan barang keluar dan struk barang masuk dan keluar 
Hal : $158-175$

2. Bagian Gudang

a. Bagian gudang hanya dapat menambahkan data barang masuk, mengecek stok barang yang tersedia dan mencatat barang keluar

b. Proses yang terjadi pada sistem bagian gudang terdapat proses login, proses cetak barang masuk.

c. Keluaran yang dihasilkan oleh aplikasi yaitu informasi cetak struk barang masuk.

d. Menghitung semua jumlah barang yang tersedia digudang agar terkontrol, dan dilakukan hanya sebulan sekali (stock opname)

\subsection{Perancangan Sistem Usulan}

\subsubsection{Tahapan Perancangan Sistem}

\section{A. Analisis Kebutuhan}

1. Analisa Kebutuhan Pengguna

Dalam aplikasi Persedian Barang terdapat dua pengguna yang dapat saling berinteraksi dalam lingkungan system, yaitu: Admin, dan Bagian Gudang. Kedua pengguna tersebut memiliki karakteristik interaksi dengan system yang berbeda-beda dan memiliki kebutuhan informasi yang berbeda-beda, seperti berikut :

a. Skenario Kebutuhan Admin
1) Mengelola Data Persediaan Barang
2) Mengelola Stok Barang
3) Mengelola Barang Keluar
4) Mengelola Data Supplier
5) Mengelola Data Pelanggan
6) Membuat Laporan Barang Keluar

b. Skenario Kebutuhan Bagian Gudang

1) Mengelola Data Persediaan Barang

2) Megelola Stok Barang

3) Mengelola Barang Masuk

4) Membuat Laporang Barang dan Barang Masuk

2. Analisa Kebutuhan Sistem

a. Sistem menyediakan login untuk admin dan bagian gudang agar keamanan data terjaga.

b. Sistem mampu megelola stok barang masuk dan barang keluar.

c. Sistem mampu mencatat semua transaksi barang masuk dan barang keluar dan memberikan laporan barang masuk dan barang keluar. 


\subsubsection{Rancangan Diagram Use Case}

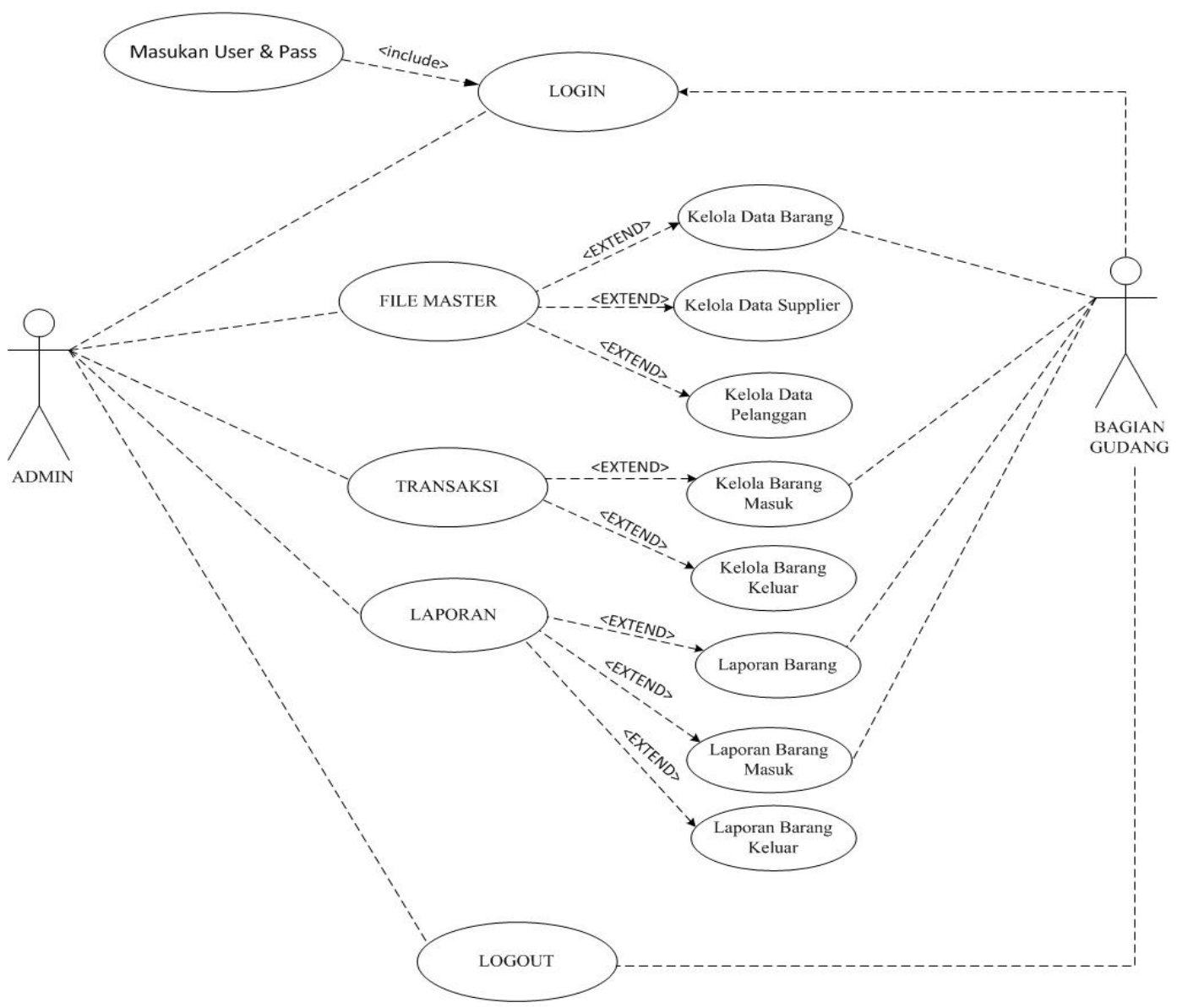

Gambar III.1.

Use Case Diagram Sistem Persediaan Barang

Tabel III.1.

Deskripsi Use Case Sistem Persediaan barang

\begin{tabular}{|l|l|}
\hline Usa case name & Persediaan Barang \\
\hline Requirements & $\begin{array}{l}\text { Admin Dapat melihat stock barang dan melakukan } \\
\text { proses barang keluar }\end{array}$ \\
\hline Pre-Condition & $\begin{array}{l}\text { Admin melakukan proses barang keluar kepada } \\
\text { Pelanggan }\end{array}$ \\
\hline Past Condition & Admin memproses barang keluar pelanggan \\
\hline Failed end conditions & $\begin{array}{l}\text { Barang Keluaar gagal, data tidak disimpan dalam } \\
\text { database }\end{array}$ \\
\hline Primary Actors & Admin \\
\hline
\end{tabular}


Hal : $158-175$

\begin{tabular}{|l|l|}
\hline Main Flow / Basic Path & $\begin{array}{l}\text { 1. Admin menerima PO / SP dari salesaman } \\
\text { 2. Admin membuat data barang keluar menjadi } \\
\text { faktur dan di berikan ke bagian gudang }\end{array}$ \\
& $\begin{array}{l}\text { 3. Bagaian gudang menyiapakan barang sesuai } \\
\text { faktur }\end{array}$ \\
4. Admin mencetak faktur dan di serahkan kepada \\
expedisi
\end{tabular}

\subsubsection{Rancangan Diagram Aktivitas}

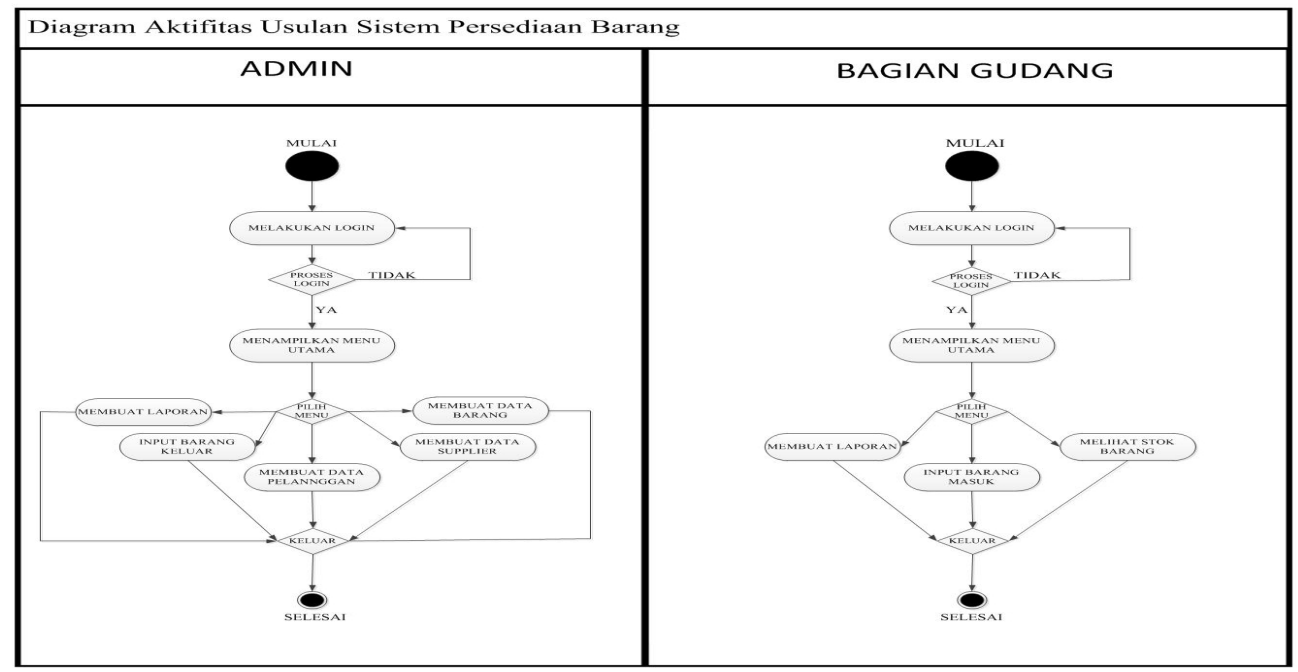

Gambar III.2. Aktivitas Diagram Sistem Persediaan Barang 
Hal : $158-175$

3.5. Perancangan Perangkat Lunak

3.5.1. Entity Relationship Diagram (ERD)

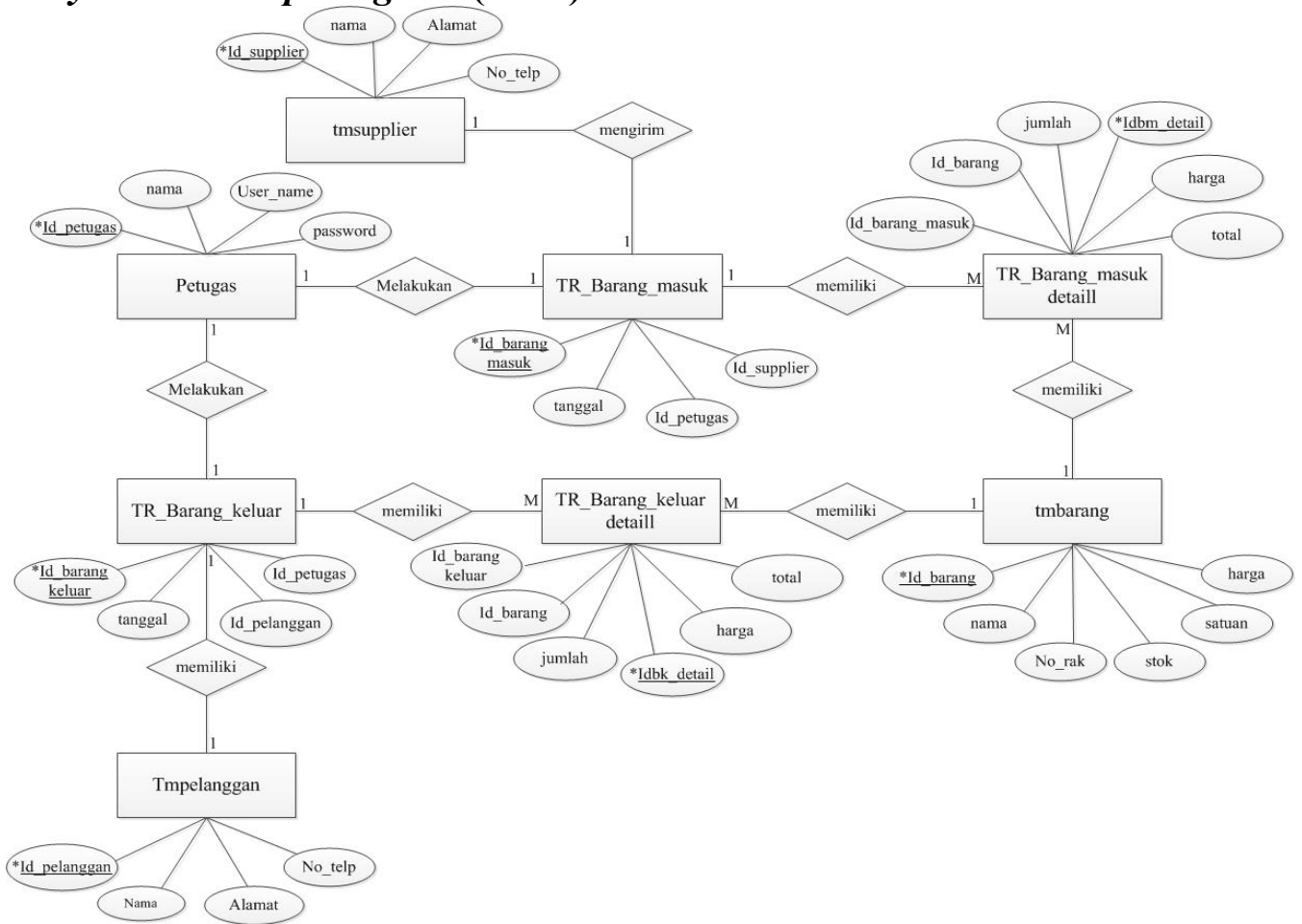

Gambar III.3.

Entity Relationship Diagram Sistem Persediaan Barang

\subsubsection{Logical Record Structure (LRS)}

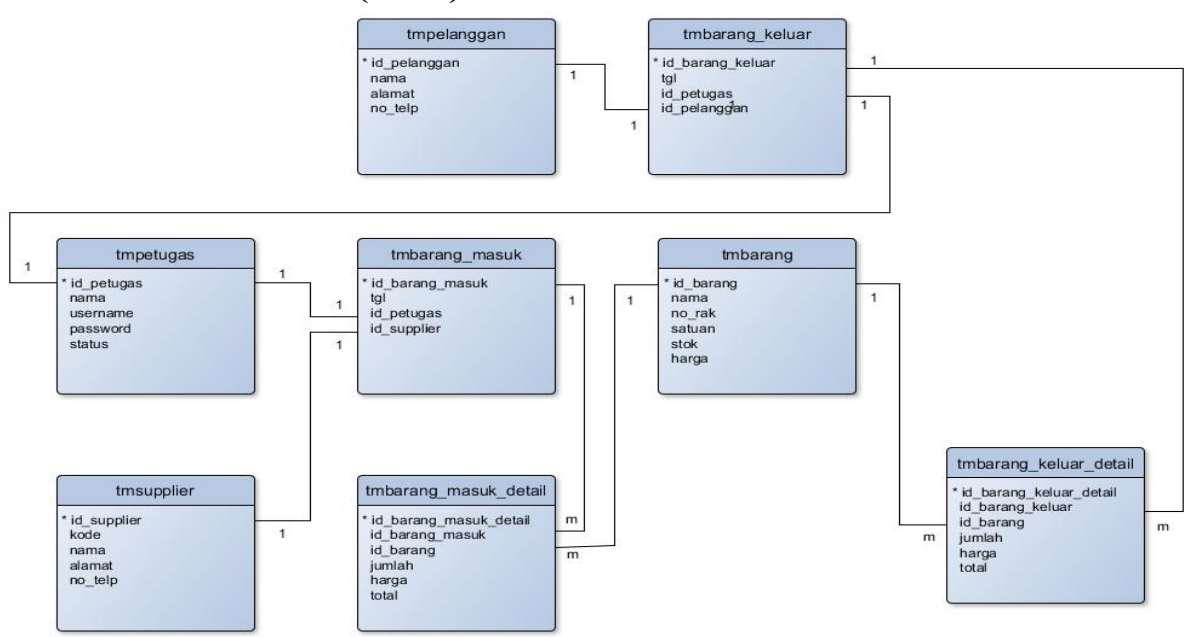

Gambar III.4.

Logical Record Structure Sistem Persediaan Barang 
Hal : $158-175$

\subsubsection{Class Model / Class Diagram}

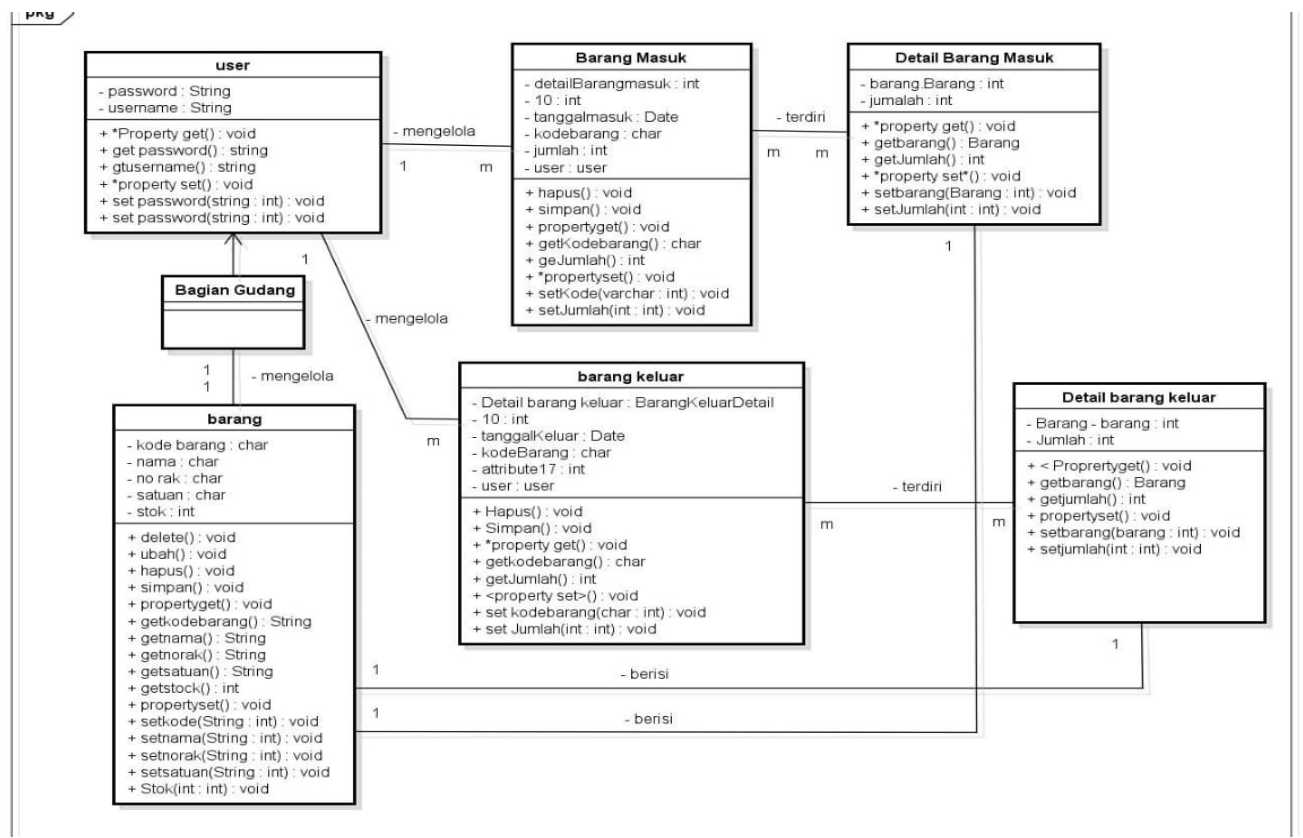

Gambar III.5.

Class Diagram Sistem Persediaan Barang

\subsubsection{Sequence Diagram}

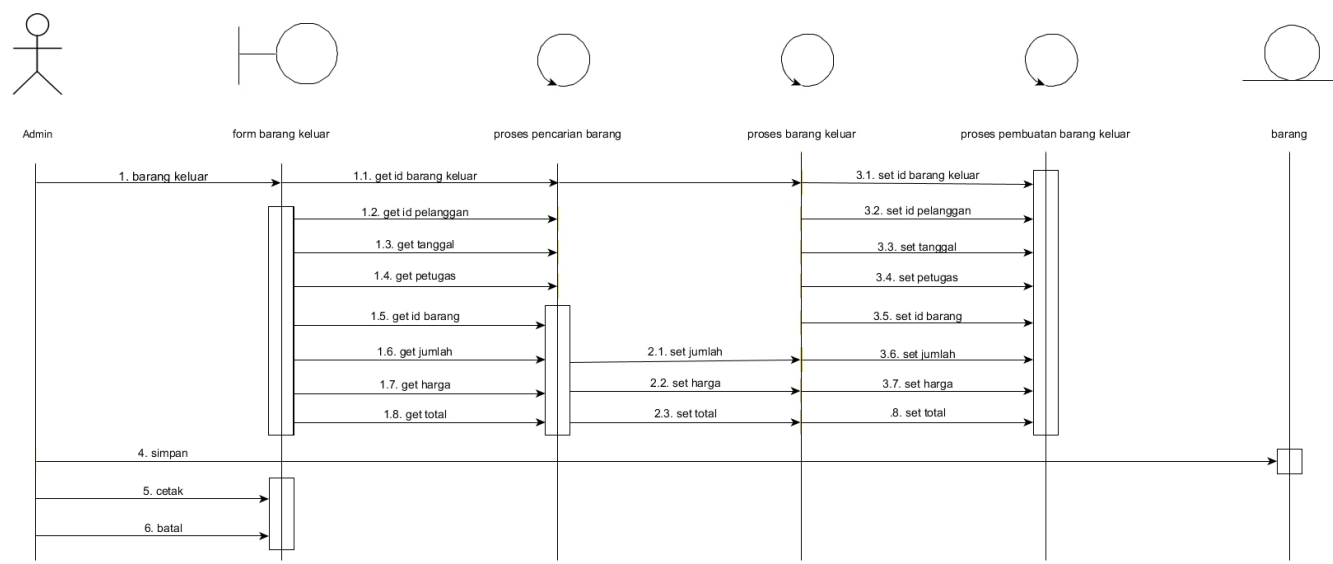

Gambar III.6.

Sequence Diagram Sistem Persediaan Barang 
Hal : $158-175$

\section{HASIL DAN PEMBAHASAN}

1. Login Admin dan Bagian Gudang

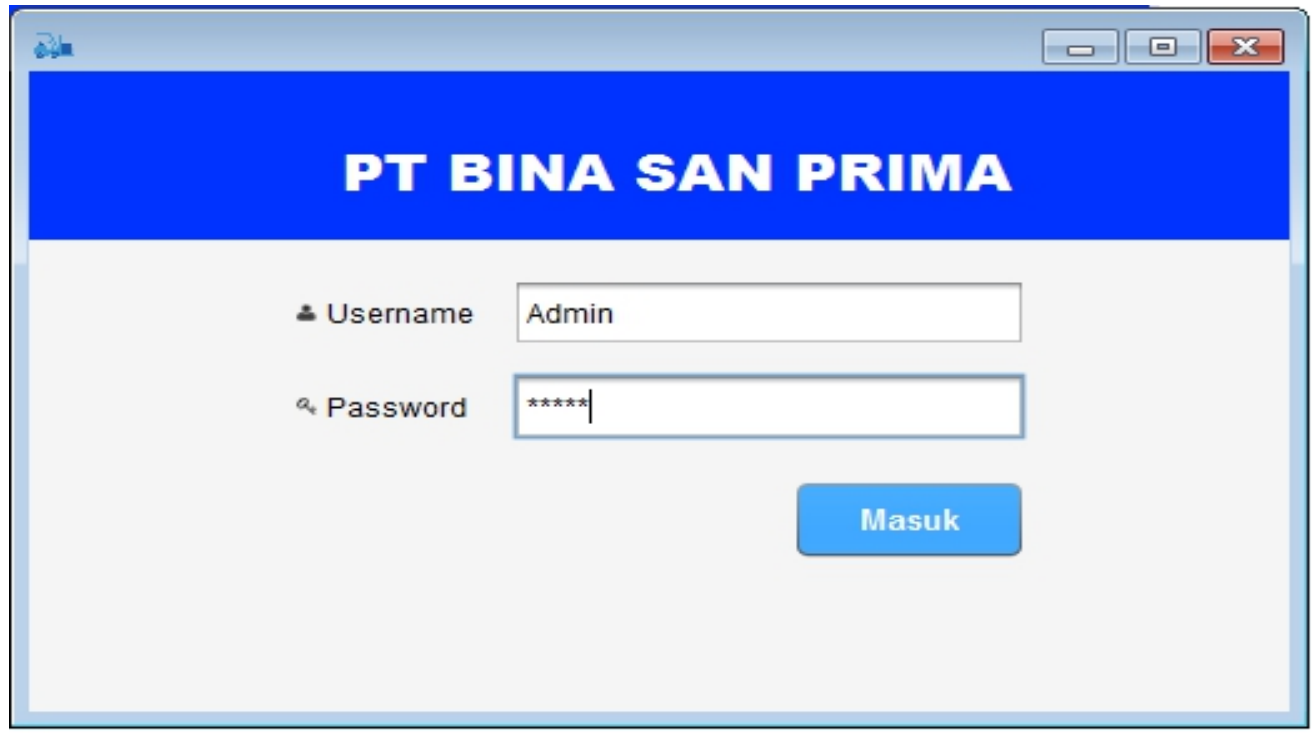

Gambar IV.1.

Form Login Admin Dan Bagian gudang

2. Form Menu Utama

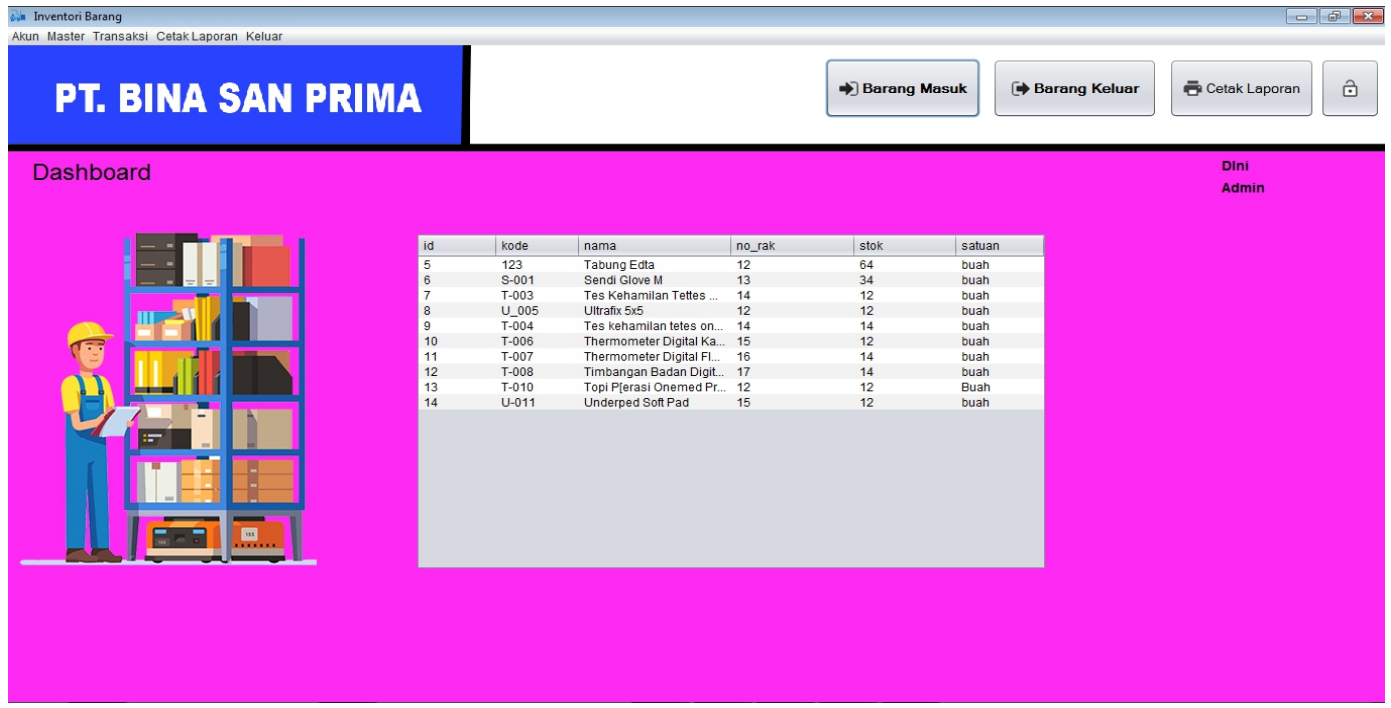

Gambar IV.2.

Form Menu Utama 
Hal : $158-175$

3. Profil Pegawai

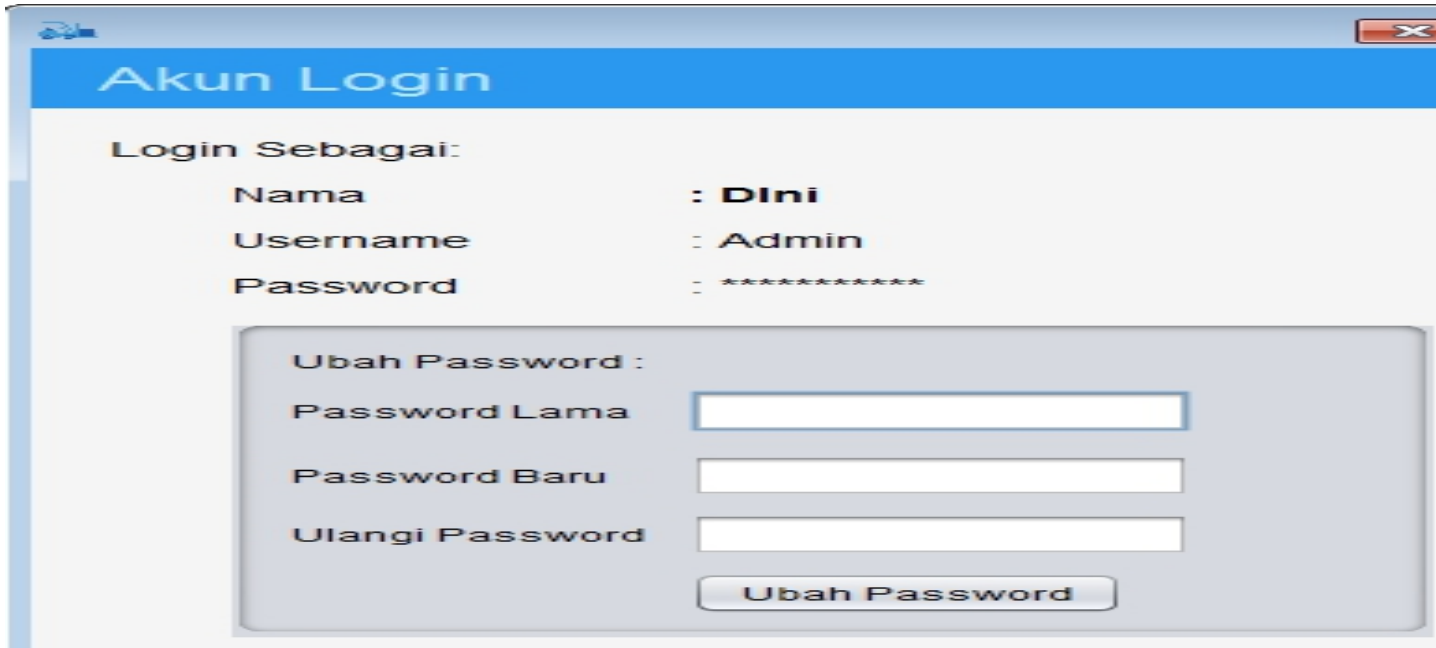

Gambar IV.3.

Form Profil Pegawai

4. Data Persediaan Barang

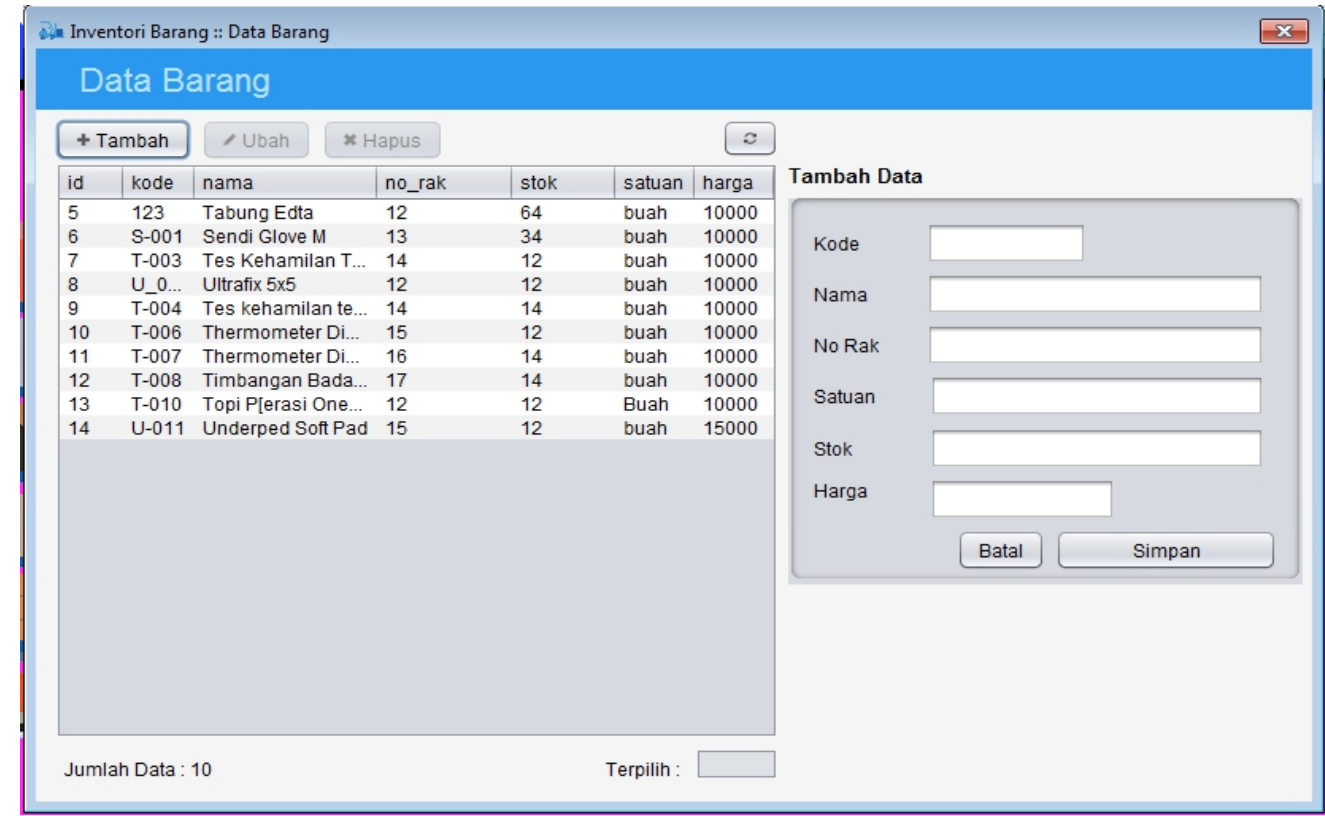

Gambar IV.4.

Form Data Persediaan Barang 
Hal : $158-175$

5. Data Supplier

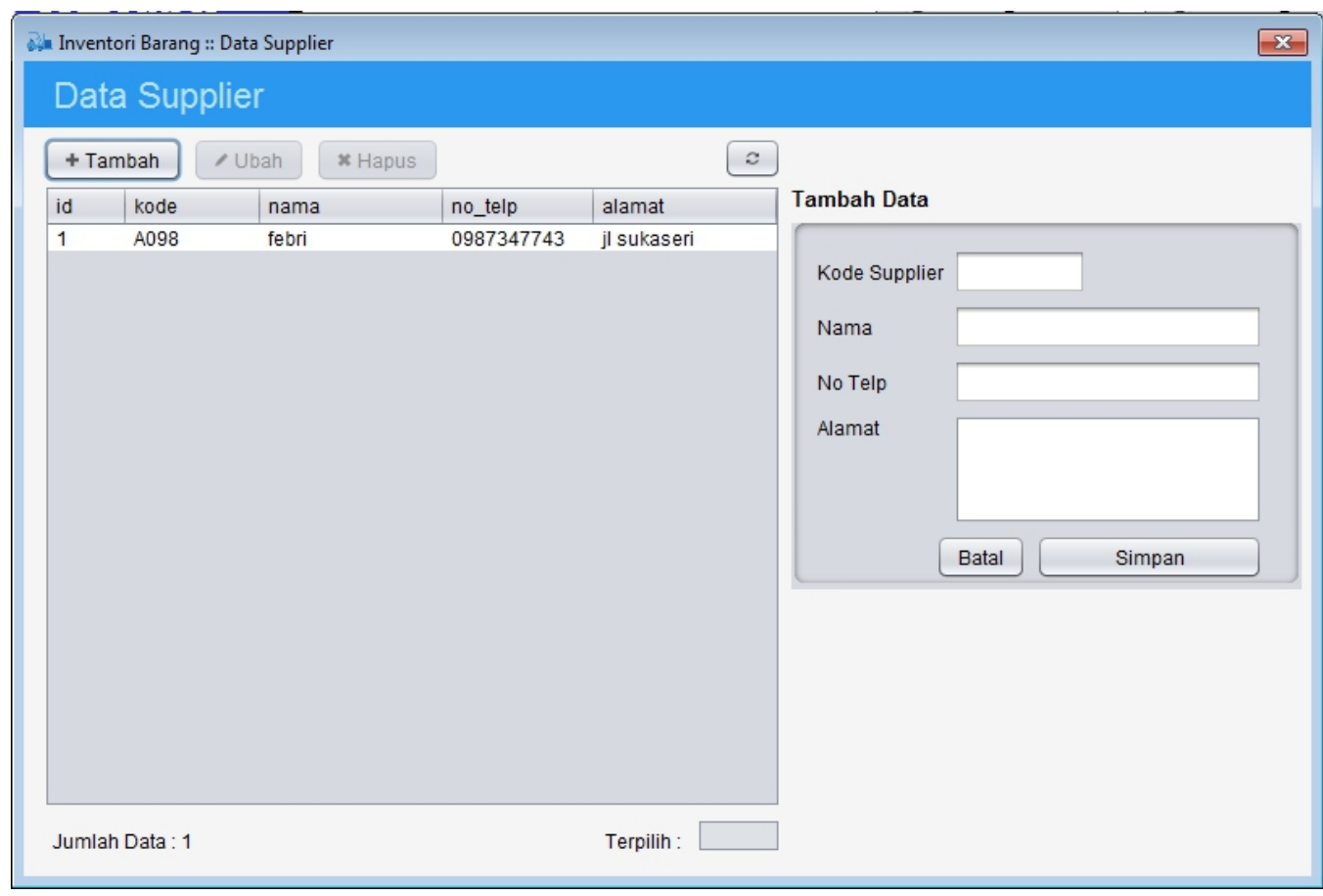

Gambar IV.5.

Form Data Supplier

6. Data Pelanggan

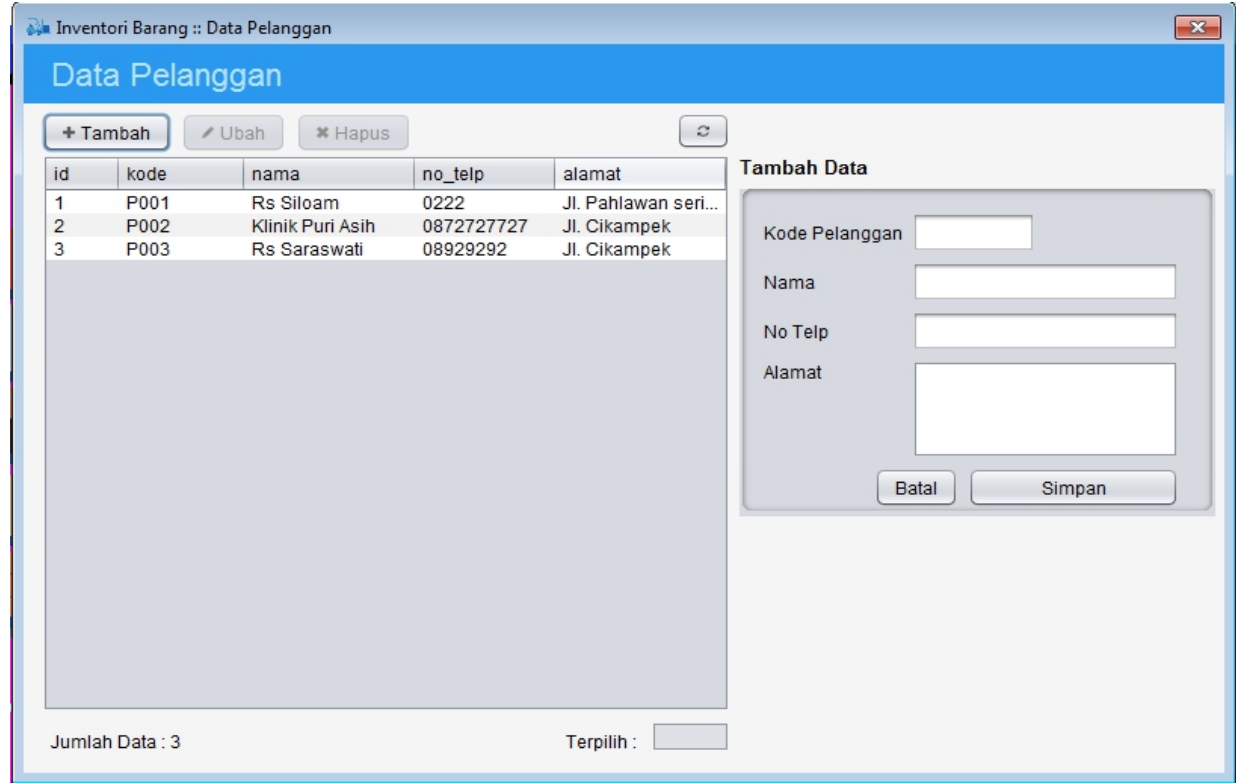

Gambar IV.6.

Form Data Pelanggan 
Hal : $158-175$

7. Data Pegawai

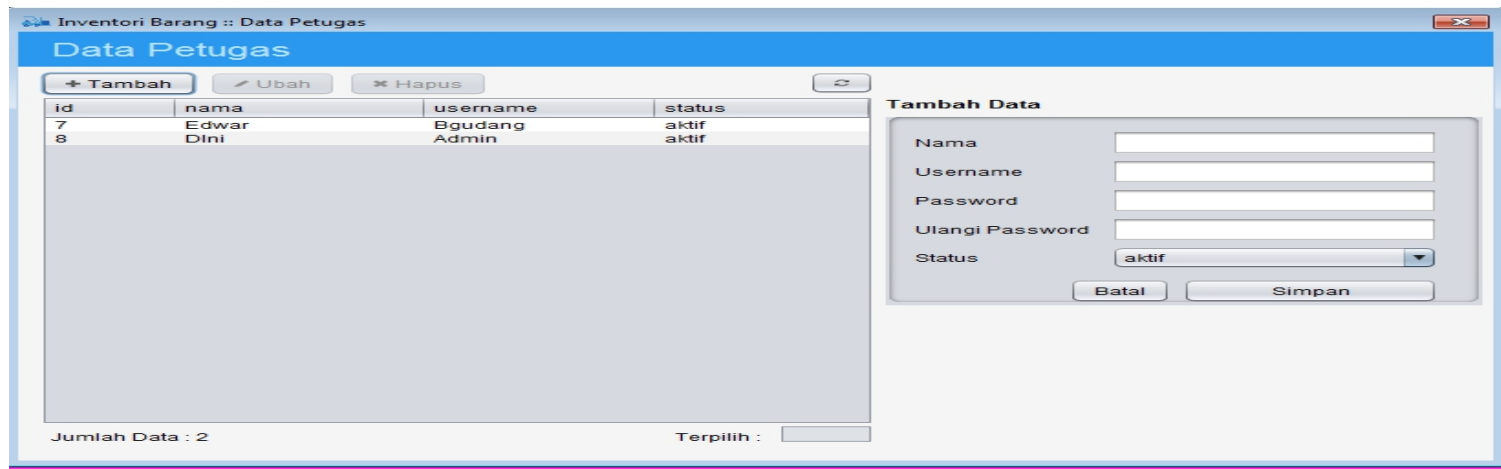

Gambar IV.7.

Form Data Pegawai

8. Form Barang Masuk

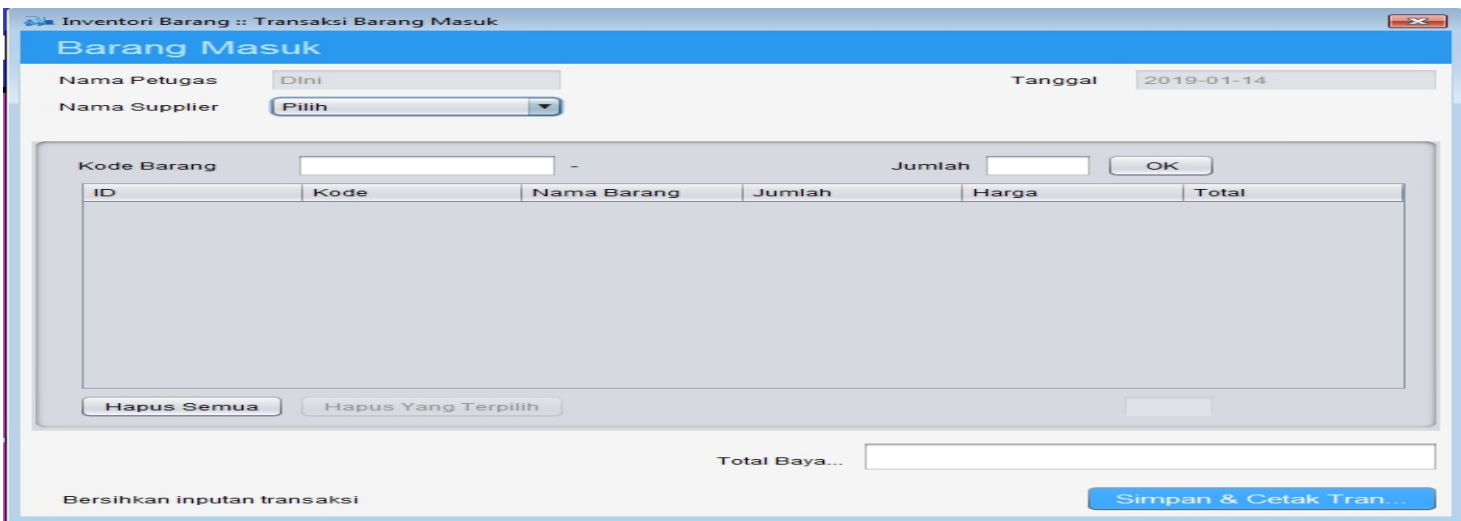

Gambar IV.8.

Form Barang Masuk

9. Form Barang Keluar

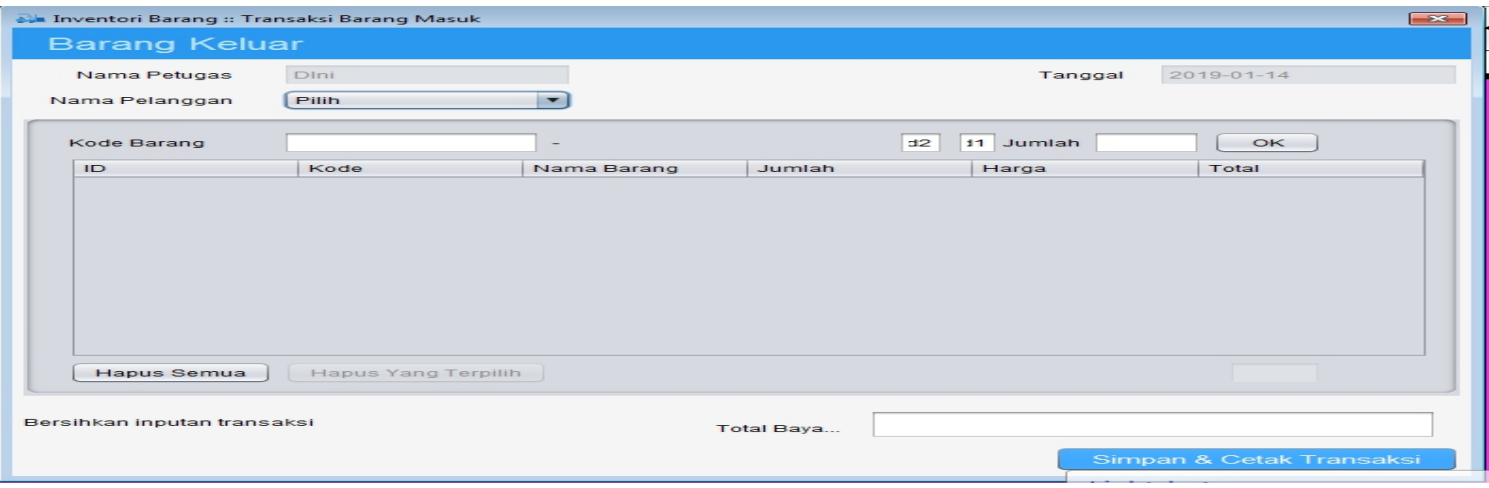

Gambar IV.9.

Form Barang keluar 
Hal : $158-175$

10. Cetak Laporan

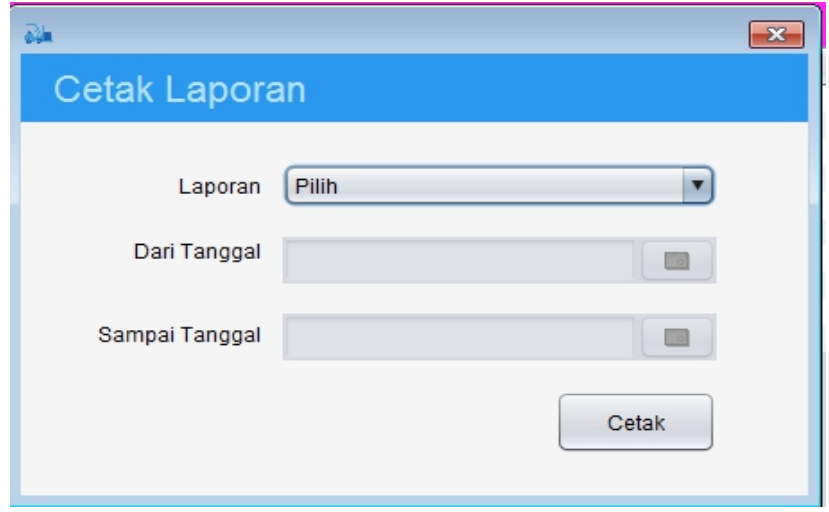

Gambar IV.10.

Form Cetak Laporan

11. Laporan Persediaan

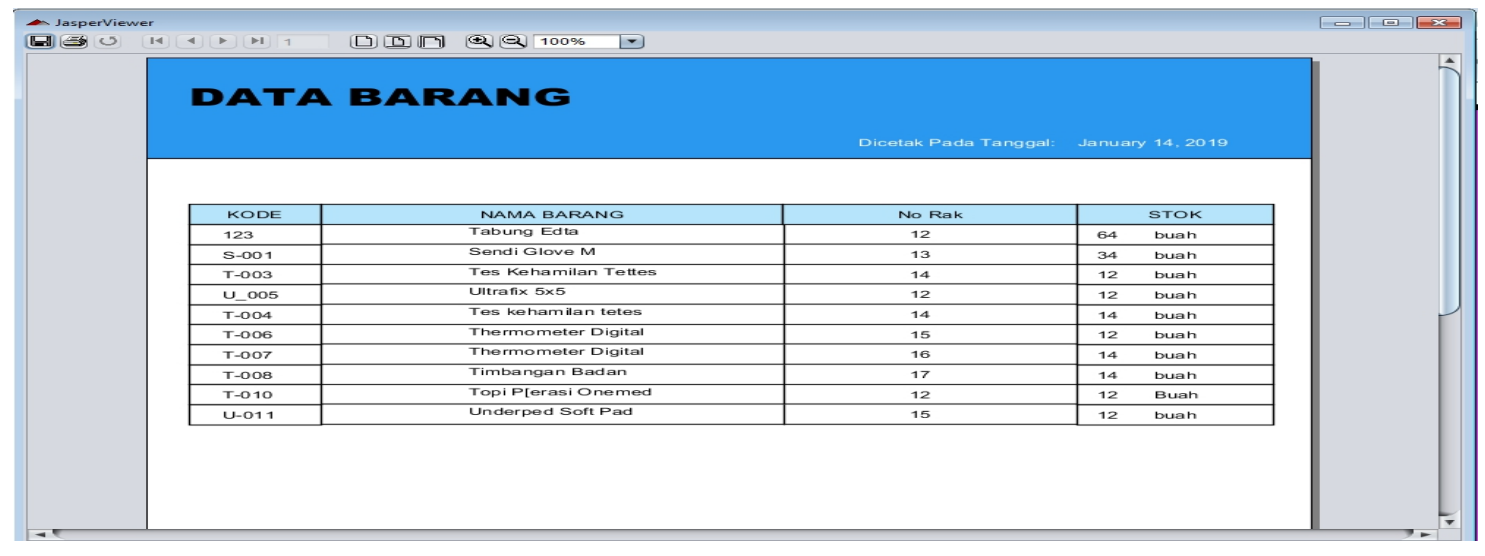

Gambar IV.11.

Form Laporan Persediaan Barang 


\section{Kesimpulan dan Saran}

\subsection{Kesimpulan}

Berdasarkan hasil riset yang dilakukan pada sistem persediaan barang khususnya yang diterapkan pada PT. Bina San Prima, akhirnya dapat diambil kesimpulan sebagai berikut:

a. Sistem berjalan masih menggunakan cara manual sehingga sering terjadi kesalahan dan pemalsuan data.

b. Keamanan data kurang terjamin karena dalam pencatatannya masih mengguunakan kertas sehingga sering terjadi hilangnya data atau rusak karena usia.

c. Aplikasi program merupakan alternatif pemecahan dari masalah yang dihadapi oleh perusahaan-perusahaan atau pun instansi, PT. Bina San Prima dalam hal ini khususnya pembuatan laporan persediaan barang. Dengan adanya aplikasi pemrograman ini pengisian dan penyimpanan data akan menjadi mudah dan lebih aman, apabila kita ingin mengetahui data atau laporan yang lain, dengan mudah kita mengetahuinya, tanpa harus membuka satu persatu lembar-lembaran dokumen yang bertumpuk dan berdebu.

\subsection{Saran}

Berdasarkan hasil riset yang dilakukan sistem persediaan barang khususnya yang diterapkan pada PT. Bina San Prima, dapat diambil Saran dari seluruh pokok bahasan adalah sebagai berikut :

a. Buat file back up agar data-data tersebut dapat terjaga keamanannya dari kerusakan atau kehilangan akibat pemakai komputer maupun virus komputer itu sendiri.

b. Penggunaan komputer menuntut kedisiplinan para pemakainya, terutama dalam menyimpan data masukan. Dalam proses pemasukan data diharapkan admin juga dituntut lebih teliti sebab kesalahan yang kecil dapat berakibat fatal. Untuk itu perlu diadakan pelatihan dan penjelasan bagi admin yang berhubungan dengan program maupun pembuatan laporan pada PT. Bina San Prima, Yang seoptimal mungkin sehingga tidak terjadi hal-hal yang sangat merugikan admin maupun pihak perusahaan.

c. Pengecekan data yang tersimpan pada computer sebaiknya dilakukan secara berlaka, misalnya satu bulan atau setiap tahun ajaran baru.

d. Sebaiknya perusahaan melakukan pelatihan kerja terhadap karyawannya untuk meningkatkan kualitas dan kemampuan dalam mengoprasikan komputer. Disamping itu perlu dilakukan juga pemeliharaan terhadap perangkat lunak (software) maupun perangkat kerasnya (hardware) demi kelancaran tugas. 


\section{DAFTAR PUSTAKA}

Ade Hendini. 2016. Pemodelan UML Sistem Informasi Monitoring Penjualan Dan Stok Barang (Studi Kasus: Distro Zhezha Pontianak). Vol. 4 No 2, Desember 2016.

Anggy Listiani, Sulistya Dewi Wahyuningsih, 2019, Analisis Pengelolaan Persedian Barang Dagang Untuk Mengoptimalkan Laba Jurnal PETAe, Vol. 4 No. 1 Januari 2019 Hal 95103.

Djahir, Yulia dan Dewi Pranita. 2015. Sistem Informasi Manajemen. Yogyakarta: CV. Budi Utama.

Erwin Suhandono dan Arif Hidayat, Sistem Informasi Pengelolaan Barang Persediaan Milik Negara Di Pusat Penilaian Pendidikan, Jakarta, Jurnal Ilmiah Rekayasa \& Inovasi Volume 2.1, Januari 2020.

Faisal Fajar Nursaid, Adam Hendra Brata, Agi Putra Kharisma, Program Pengembangan Sistem Informasi Pengelolaan Persediaan Barang Dengan React J S Dan React Native Menggunakan Prototype (Studi Kasus : Toko Uda Fajri), Malang, Jurnal Pengembangan Teknologi Informasi dan Ilmu Komputer 964XVol. 4, No. 1, Januari 2020, hlm. 46-55.

Hayuningtityas, Ratih Yulia. 2018. Sistem Informasi Persediaan Barang Menggunakan Unified Software Development Process Pada Toko Alat Kesehatan. Vol. 6 No 2, Juli 2018.

Hikmah, Agung Baitul, Dedy Supriadi, dan Tuti Alawiyah. 2015. Cara Cepat Membangun Website dari Nol. Yogyakarta: CV. Andi Offset

Junianto, Erfian, dan Yusa Primaesha. 2015. Perancangan Sistem Tracking Invoice Laboraturium pada PT Sucufindo (Persero) Bandung. Vol. 2 No 2, Semptember 2015.

Maulana Hasanudin, Rancang Dan Bangun Sistem Informasi Inventori Barang berbasis Web(Studi Kasus Pt. Nusantara Sejahtera Raya), Bogor, Jurnal IKRA-ITH Informatika Vol 2 No 3 November 2018 Hal 1-14 (November 2018),

Nofriadi. 2018. Java Fundamental dengan Netbeans 8.0.2. Yogyakarta: CV. Budi Utama.

Su Rahman. 2014. Bengkel Web \& SEO Joomla. Jakarta: PT. Elex Media Komputindo.

Sulianta, Feri, dan Fajri Rakhmat Umbara. 2015. Teknik Hebat Merancang Aplikasi Instan Berkualitas. Jakarta: PT. Elex Media Komputindo.

Tri Ramdhany dan Nita Noer Hardianty Aplikasi Persediaan Barang Dagang Berbasis Komputer Di Bagian Gudang Pada PT. Grafindo Media Pratama, Bandung, 
Hal : $158-175$

Jurnal_Tri_Ramdhany_Aplikasi_Persediaan_Barang_Dagang_Berbasis_Komputer_Di_B agian_Gudang_Pada_Pt_Grafindo_Media_Pratama.

Yurindra. 2017. Software Engineering. Yogyakarta: CV. Budi Utama.

Yuyus Dwi Kusuma Wardana, Analisa Sistem Pengelolaan Persediaan Barang Dagangan Dan Pembelian Barang Dagangan, Jurnal PETA Vol. 1 No. 1 ,Juli 2016 Hal 40-53, 